Тетяна Романченко

\title{
ПРОСТОРОВА ТРАНСФОРМАЦІЯ ЕКОНОМІКИ: ЛОКАЛЬНИЙ РІВЕНЬ (НА ПРИКЛАДІ С. ГЕЛЬМЯЗІВ ЧЕРКАСЬКОЇ ОБЛАСТІ)
}

Татьяна Романченко

\section{ПРОСТРАНСТВЕННАЯ ТРАНСФОРМАЦИЯ ЭКОНОМИКИ: ЛОКАЛЬНЫЙ УРОВЕНЬ (НА ПРИМЕРЕ С. ГЕЛЬМЯЗОВЕ ЧЕРКАССКАЯ ОБЛАСТЬ)}

Tetiana Romanchenko

\section{SPATIAL TRANSFORMATION OF THE ECONOMY: LOCAL LEVEL (ON THE EXAMPLE OF GELMYAZIV OF CHERKASY REGION)}

У статті проаналізовано особливості сталого розвитку населеного пункту локального рівня через показники умов життя населення. Здійснено соціальне опитування населення сільської місиевості з метою дослідження суб'єктивного сприйняття умов життя та достатку. Здійснено огляд літературних джерел із визначенням взаємозв'язків між процесами сочіальної поляризачї населення за майновим принципом та сталим розвитком на локальному рівні. Запропоновано методику оцінювання бідності / заможності домогосподарств на локальному рівні в контексті поляризації сочіально-економічного простору на території населеного пункту. Застосовано ГІСінструментарій для дослідження просторових процесів на локальному рівні. Запропоновано використання механізмів стимулювання сталого розвитку регіону (на основі інноваційної політики смартспеціалізаціі) для соціальноекономічного вирівнювання територіальних диспропорцій.

Ключові слова: сталий розвиток; населення; локальний рівень; смартспеціалізація.

Рис.: 2. Табл.: 1. Бібл.: 18.

В статье проанализированы особенности устойчивого развития населенного пункта локального уровня через показатели условий жизни населения. Осуществлен социальный опрос населения сельской местности с иелями исследования субъективного восприятия условий жизни и достатка. Осушествлен обзор литературных источников по определению взаимосвязей между процессами социильной поляризации населения по имущественному приниипу и устойчивым развитием на локальном уровне. Предложена методика оченки бедности / богатства домохозяйств на локальном уровне в контексте поляризачии сочиально-экономического пространства на территории населенного пункта. Применен ГИС-инструментарий для исследования пространственных процессов на локальном уровне. Предложено использование механизмов стимулирования устойчивого развития региона (на основе инновачионной политики смарт-специализации) для социально-экономического выравнивания территориальных диспропорций.

Ключевые слова: устойчивое развитие; населения; локальный уровень; смарт-специализачия.

Рис.: 2. Табл.: 1. Библ.: 18.

The article analyzes the features of sustainable development of the settlement at the local level through indicators of living conditions. A social survey of the rural population was conducted to study the subjective perception of living conditions and wealth. A review of literature sources with the definition of the relationship between the processes of social polarization of the population on the property principle and the formation of the processes of spatial transformation of the economy at the local level. A method for estimating poverty / wealth of households at the local level in the context of polarization of socioeconomic space in the settlement is proposed. GIS tools have been used to study spatial processes at the local level. The use of mechanisms to stimulate sustainable development of the region (based on the innovative policy of SMART-specialization) for the socio-economic equalization of territorial disparities is proposed.

Key words: sustainable development; population; local level; SMART-specialization.

Fig.: 2. Table: 1. References: 18.

JEL Classification: Q56; R58; O32

Постановка проблеми. Сучасні процеси глобалізації відображають зміни планетарного масштабу в господарській діяльності людини та ії впливу на стан природного середовища. Наявність просторових трансформацій економік регіонів $\epsilon$ однією з ознак процесів глобалізації. Співпраця науковців цілого світу під егідою ООН довкола концепції сталого розвитку свідчить про те, що немає малих проблем: просторові трансформації економіки на локальному рівні також можуть скрупульозно бути досліджені, як i осмислення проблем найвищих рівнів. Європейська комісія розглядає саме політику смартспеціалізації (S3), як один із підходів до досягнення сталого розвитку регіон через трансформацію економіки на основі знань (інновацій). Прийнято вважати, що S3 - це про чіткий алгоритм, який допомагає спрогнозувати роботу з інноваційного розвитку, залучивши всіх ключових стейкхолдерів (науку, владу, бізнес). Як влучно зазначає Мо- 
ніке Матусяк (керівниця в регіоні Свропейської політики з розширення і сусідства), S3 означає не лише перебудову економіки України на основі знань, але ще потрібно підкреслити і процеси сталості в реагуванні на майбутні кризи та процеси відновлення. Потрібно досліджувати, як це впливає на суспільство. Нині важливими є програми зі сталого розвитку на основі S3. Це вже було зроблено на національному рівні серед кран Європи та наступним кроком $є$ розробка програм сталого розвитку на засадах S3 на регіональному та локальному рівнях.

В основі чинників просторової трансформації на локальному рівні (на прикладі с. Гельмязів Черкаської області) було використано поняття бідності та соціальних умов життя населення. Дослідження та усунення бідності є метою сталого розвитку номер 1. Використання ключових елементів концепції сталого розвитку як державного орієнтира багатьох країн світу вказує на наочність проблем в економіці природокористування людини на сучасному етапі. І саме на різних рівнях управління природокористуванням виникає потреба комплексної системи організаційно-економічних перетворень задля вирішення еколого-економічних проблем.

До завдань, які повинні бути висвітлені в цьому дослідженні, належать:

1. Здійснити аналіз літературних джерел за напрямами бідності, соціальної нерівності та умов життя населення в контексті соціально-економічної поляризації та просторової трансформації економіки на локальному рівні.

2. Розробити методику оцінки просторової трансформації економіки на локальному рівні через показники бідності / достатку та суб'єктивного сприйняття достатку.

3. Обгрунтувати необхідність впровадження механізмів стимулювання сталого розвитку регіону в контексті смартспеціалізації з метою оптимізації процесів просторової трансформації економіки.

Аналіз останніх досліджень і публікацій. Регіональний розвиток характеризується безперервністю і незворотністю перетворення капіталу та нагромадженням нових цінностей. Однієї з концепцій регіонального розвитку є сталий розвиток, який характеризується збалансуванням в економічній, екологічній та соціальній сферах регіону. Реалізація концепції сталого розвитку при управлінні регіональним розвитком забезпечує динаміку збалансованого природокористування та збереження цінних ресурсів для майбутніх поколінь [12]. Природні ресурси, людські ресурси, товари та технології $є$ безумовними факторами економічного зростання. Однак останніми роками помітний ще один фактор економічного зростання - інновації. Інновації забезпечують можливості. Це рекомендується враховувати регіонам, які намагаються вийти з кризи [18]. Перетворення регіональної економіки на основі знань (смартспеціалізація) розглядається сучасними науковцями, як один із підходів до досягнення першої мети сталого розвитку - подолання бідності. Саме бідність у цьому ключі розуміється як «соціально-економічне й соціокультурне явище, що відображає стан буття населення» [5]. При економічних підходах бідність ототожнюється з відсутністю доходів (дохід визначає матеріальний рівень достатку). Із таких позицій були обгрунтовані поняття мінімального споживчого бюджету, межі бідності, прожиткового мінімуму. Сучасна бідність населення трактується не тільки як економічний і соціально-культурний стан груп населення з обмеженням доступу до ресурсів, а й особливий спосіб і стиль життя, норми поведінки, стереотипи сприйняття та психології, що передаються з покоління в покоління [10].

У регіональних дослідженнях категорія «бідність» була розглянута й обгрунтована Н. Гаєвською: «масштабна бідність населення - явище, яке заважає формуванню в суспільстві середнього класу, який у свою чергу виступає головним регулятором загального соціально-економічного прогресу і сталого позитивного розвитку держави, стримує її економічний розвиток, негативно позначається на характері демографічних процесів» [5]. 
ПРОБЛЕМИ МЕНЕДЖМЕНТУ ТА РОЗВИТКУ ПРОДУКТИВНИХ СИЛ РЕГІОНУ

Питання структури бідності за групами ризику та визначення критеріїв і кількісних оцінок розглядали різні вчені: В. Добренькова, І. Гнібеденко, А. Колота, А. Кравченко, Е. Лібанова, В. Мандибура, С. Мельник, А. Мігранова, Т. Новікова, Л. Овчарова, Е. Ольшанська, Н. Рімашевська, М. Соколик, А. Шевякова та ін. Серед наявних просторових досліджень варті уваги роботи таких фахівців, як Т. Богомолова, І. Думова, Н. Зубаревич, С. Лаптєва, І. Мельник, В. Тапіліна, О. Черкашина, О. Хомра, Н. Гаєвська.

Вітчизняні дослідження, які можна розглядати як такі, що стали основоположними при вивченні просторових трансформацій економіки, були започатковані в регіональних студіях. Інтерес до просторового аналізу соціально-економічних процесів з погляду якості життя населення посилюється 3 кінця 80 -х років та $є$ найбільш актуальним після 2010 р. в Україні [6; 8; 11; 16].

Міждисциплінарні регіональні дослідження здійснюються різними фахівцями, зокрема економістами, географами, архітекторами, містобудівельниками, екологами, у контексті розроблення стратегій регіонального розвитку, генеральних планів, проєктів ОТГ [2; 4]. Одним із прикладів таких досліджень останніми роками є праця С. Покляцького, в якій запропоновано методику дослідження умов життя, яка грунтується на поєднанні статистики й результатів анкетного опитування. На цій підставі С. Покляцьким проведено типізацію 45 великих міст України за специфікою формування економічної, соціальної, екологічної та соціокультурної складових умов життя і визначено пріоритетні напрями поліпшення умов життя населення у великих містах України, розкрито шляхи вдосконалення організаційного механізму управління їх розвитком [9].

В Україні починаючи з 1980-х рр. складається школа оцінки умов життя в архітектуpi та житловому будівництві, iіi представники - Д. Богорад, О. Фомін, Г. Фільваров, Г. Смоляр, М. Дьомін, В. Нудельман та ін. [7].

Формування способу життя населення залежно від територіального розміщення (на прикладі міст і сіл) досліджували географи-регіоналісти - Ю. Пітюренко, П. Коваленко, А. Степаненко, Г. Підгрушний, П. Масляк, С. Іщук та ін. [1; 3].

Аспекти територіальних відмінностей у задоволенні повсякденних потреб населення були досліджені в роботах Л. Меркушевої, Б. Родомана, О. Ткаченка, Г. Рогожина, В. Юрківського, О. Любіцевої тощо [3].

У західній літературі поняття бідності розкривається на основі показників суб'єктивного благополуччя [13]. При таких підходах враховуються доходи європейців та особисте сприйняття їх людиною, що порівнює свій добробут 3 добробутом друзів [14]. Спостерігається неухильний інтерес економістів до різноманітних досліджень щастя людини. Досліджується, як зміни доходів, безробіття та інфляція впливають на щастя, а також зокрема, як тип демократії і ступінь децентралізації державного правління впливають на задоволення індивідом його життя. Виявляються наслідки економічної політики на життя людей [15]. Carol Graham виявляє також парадокс щасливих селян і нещасливих мільйонерів, поглиблено досліджуючи сприйняття життя і щастя в різних країнах і регіонах, зокрема й у Центральній Азії та Афганістані. Отримані дані за результатами опитування в Латинській Америці, вказують, як різний стан здоров’я впливає на задоволення здоров'ям і життям людей у різних соціально-економічних групах у різних країнах [17].

Отже, бідність $є$ не тільки глобальним та поширеним явищем у світі. Бідність $є$ цікавою проблемою з погляду іï вирішення міжнародними інституціями. I сучасні методи регіонального розвитку загострені на дослідження умов та способу життя населення 3 метою розширення інструментів впливу економічної політики. Методика JRC зі смартспеціалізації передбачає дослідження умов життя населення з метою встановлення подальшого діалогу між гравцями регіонального розвитку (населенням, бізнесом, науковцями та владою). 
Виділення недосліджених частин загальної проблеми. У цій роботі зроблено спробу моделювання суспільних відносин на локальному рівні через критерії зовнішнього вигляду домогосподарств. Недослідженими частинами роботи залишаються такі питання:

- формування стійких соціальних територіальних зв’язків на основі матеріального достатку домогосподарств;

- вплив II етапу смартспеціалізації (процесу підприємницького відкриття) на подолання бідності на території (досягнення Ц1 сталого розвитку).

Головною метою цієї роботи є виявлення місцевої специфіки функціонування економіки домогосподарств на локальному рівні, зокрема дослідження соціальноекономічної взаємодії в межах населеного пункту та в подальшому розкриття впливу смартспеціалізації на досягнення цілей сталого розвитку, зокрема - подолання бідності, голоду, досягнення екологічної стійкості та рівноваги, економічного розвитку та інноваційної діяльності. Метою роботи на довгострокову перспективу є актуалізація впливу процесу смартспеціалізації на соціо-еколого-економічні системи локального рівня в українських регіонах у відповідність до промислової політики ЄС при підтримці країн Східного партнерства.

Виклад основного матеріалу. Особливості сталого розвитку на локальному рівні досліджувались через показники умов життя в сільському населеному пункті за авторською методикою оцінювання зовнішнього вигляду домогосподарств. Використовувалась п'ятибальна шкала оцінювання, що відображала господарський стан домогосподарства та можлива роль його власника в суспільному житті села. За рівнем благоустрою були виділені такі типи домогосподарств: злиденні, незаможні, відносно заможні, середньозаможні та заможні. Ці показники вказували на спосіб життя населення, на особливості економічної і соціальної активності на території (рис. 1).

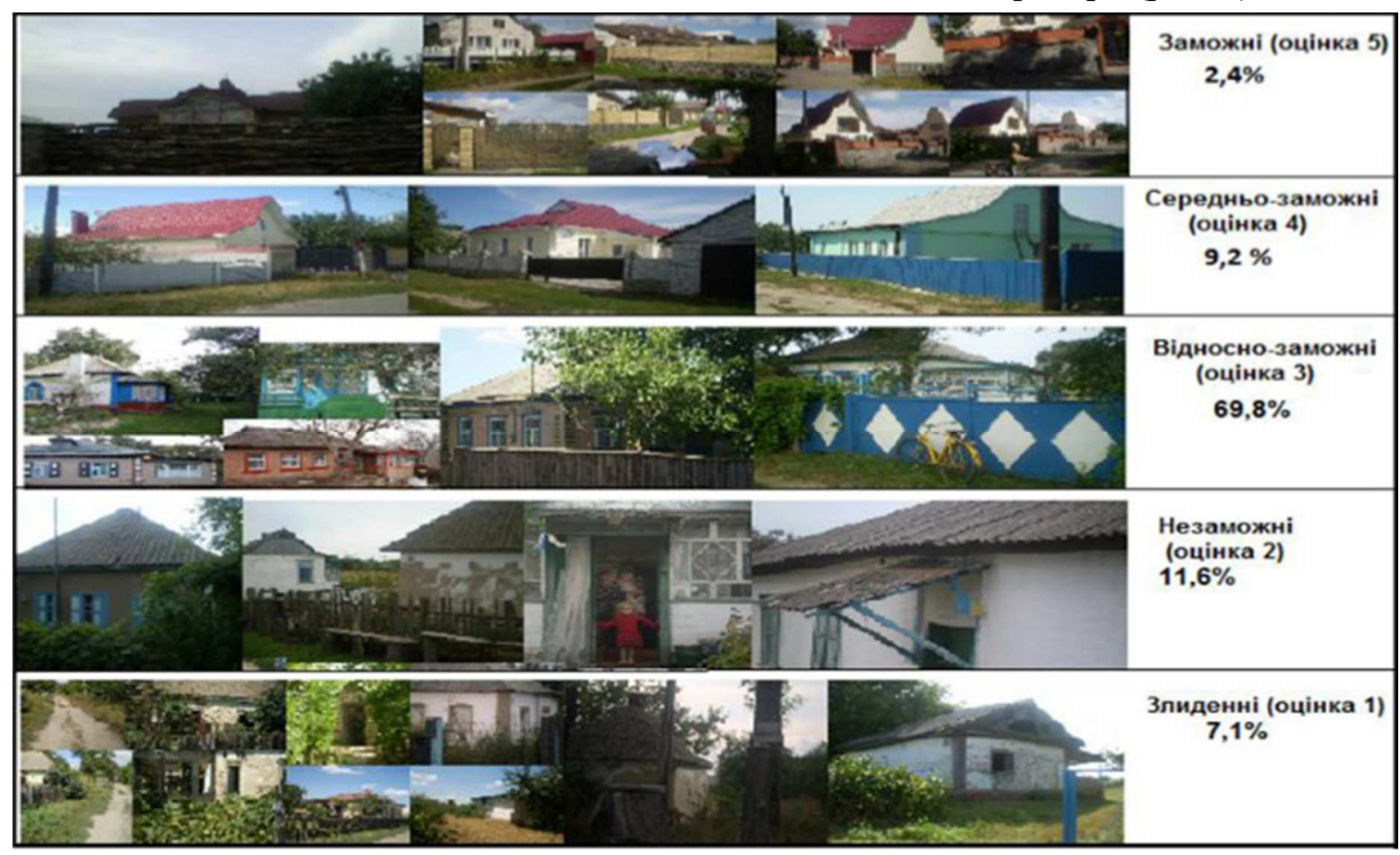

Рис. 1. Класифікація будинків за станом бідності / заможності

За сукупністю показників вулиці було згруповано таким чином (таблиця). 
ПРОБЛЕМИ МЕНЕДЖМЕНТУ ТА РОЗВИТКУ ПРОДУКТИВНИХ СИЛ РЕГІОНУ

Таблиця

Типізація вулиць (складено автором за результатами польового дослідження)

\begin{tabular}{|c|c|c|c|c|c|c|c|}
\hline \multirow{2}{*}{\multicolumn{2}{|c|}{ ритерії }} & \multicolumn{6}{|c|}{ Типізація вулиць } \\
\hline & & \multirow{2}{*}{ 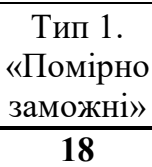 } & \multirow{2}{*}{$\begin{array}{c}\text { Тип } 2 . \\
\text { «Відносно } \\
\text { заможні» } \\
\mathbf{3 8}\end{array}$} & \multirow{2}{*}{$\begin{array}{c}\text { Тип } 3 . \\
\text { «Середні» } \\
\mathbf{6 , 6} \\
\end{array}$} & \multirow{2}{*}{$\begin{array}{c}\text { Тип 4. «Різно- } \\
\text { манітні» }\end{array}$} & \multirow{2}{*}{$\begin{array}{c}\text { Тип } 5 . \\
\text { «Бідні» } \\
\mathbf{1 0}\end{array}$} & \multirow{2}{*}{$\begin{array}{c}\begin{array}{c}\text { Тип } 6 . \\
\text { «Заможні» }\end{array} \\
\mathbf{6 , 6} \\
\end{array}$} \\
\hline & Вулиці, \% & & & & & & \\
\hline \multirow{5}{*}{ 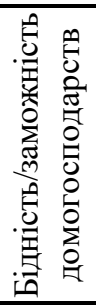 } & оцінка 1 “злиденні”, \% & 1,9 & 6,3 & 10,7 & 8,3 & 14,3 & 2,6 \\
\hline & оцінка 2 “незаможні”, \% & 2,7 & 11,2 & 9,8 & 17,7 & 16,5 & 8,8 \\
\hline & $\begin{array}{l}\text { оцінка } 3 \text { “відносно за- } \\
\text { можні”, \% }\end{array}$ & 89,7 & 76,8 & 68,5 & 62,6 & 58,7 & 38,5 \\
\hline & $\begin{array}{l}\text { оцінка } 4 \text { “середньозамо- } \\
\text { жні”, \% }\end{array}$ & 3,4 & 5,4 & 8,2 & 10,1 & 9,1 & 36,8 \\
\hline & оцінка 5 “заможні”, \% & 2,3 & 0,6 & 3,1 & 1,4 & 1,5 & 14,6 \\
\hline \multirow{3}{*}{ 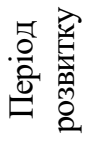 } & І пол. XX століття, \% & 2,7 & 8,1 & 3,0 & 7,8 & 10,8 & 10,8 \\
\hline & II пол. XX століття, \% & 95,6 & 90,0 & 92,5 & 83,2 & 80,9 & 80,9 \\
\hline & XXI століття, \% & 1,8 & 1,0 & 4,5 & 9,0 & 8,3 & 8,3 \\
\hline \multirow{6}{*}{ 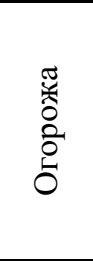 } & 3 дерева, \% & 56,0 & 40,6 & 42,5 & 36,4 & 35,0 & 23,3 \\
\hline & із заліза, \% & 16,0 & 19,9 & 15,4 & 26,9 & 16,7 & 9,4 \\
\hline & 3 шиферу, \% & 3,1 & 6,5 & 8,0 & 3,0 & 5,7 & 0,0 \\
\hline & з євро профілю, \% & 16,4 & 20,0 & 21,7 & 14,1 & 15,8 & 31,9 \\
\hline & з бетону, \% & 5,8 & 9,1 & 5,3 & 9,9 & 15,2 & 26,9 \\
\hline & відсутня, \% & 2,7 & 4,4 & 8,5 & 8,7 & 11,5 & 8,5 \\
\hline
\end{tabular}

За цією типізацією вулиць можна моделювати різні процеси й фактори, що впливають на формування різного ритму, стилю та способу життя на території. Наприклад, головною ознакою вулиць типу $1 \epsilon$ значна частка відносно заможних будинків із переважанням дерев'яних, залізних та огорож з європрофілю. На вулицях 2 типу проявляється ледь помітна зростаюча тенденція до соціально-економічного контрасту. Вулиці 3 типу характеризуються тенденцією до збіднення. Вулиці 4 типу є контрастними та мають внутрішні суперечності: одночасне розміщення бідних і заможних домогосподарств по сусідству, можливо - доглянутих і покинутих. На вулицях 5 типу найбільша частка домогосподарств без огорожі. Найбільш неоднорідною і контрастною щодо інших група вулиць $є$ група 6. У ній надзвичайно високі показники заможності (за кількістю заможних та середньозаможних домогосподарств).

На основі зібраних показників було здійснено картографічне моделювання, через яке розкривалась територіальна специфіка просторової трансформації економіки на локальному рівні (рис. 2).

Трансформація економіки через смартспеціалізацію передбачає впровадження інновацій не тільки безпосередньо на виробництві, але й у таких напрямах, як менеджмент та маркетинг (за методологією JRC смартспеціалізація передбачає інновації продукту, інновації процесів, інновації організації та маркетингові інновації). Політика впровадження смартспеціалізації, як перетворення економіки на основі знань, включає також у себе і дослідження регіонального простору на чутливість до змін. Безумовно, розуміння значення інновацій важливе не тільки в діалозі між регіональними стейкхолдерами (бізнес, наука та влада), а й на рівні місцевого соціуму. Населення є джерелом трудових ресурсів та водночас рушійною силою будь-яких соціально-економічних перетворень. 3 метою оцінки суб'єктивного сприйняття населенням благополуччя було здійснено соціальне опитування мешканців на території населеного пункту. 


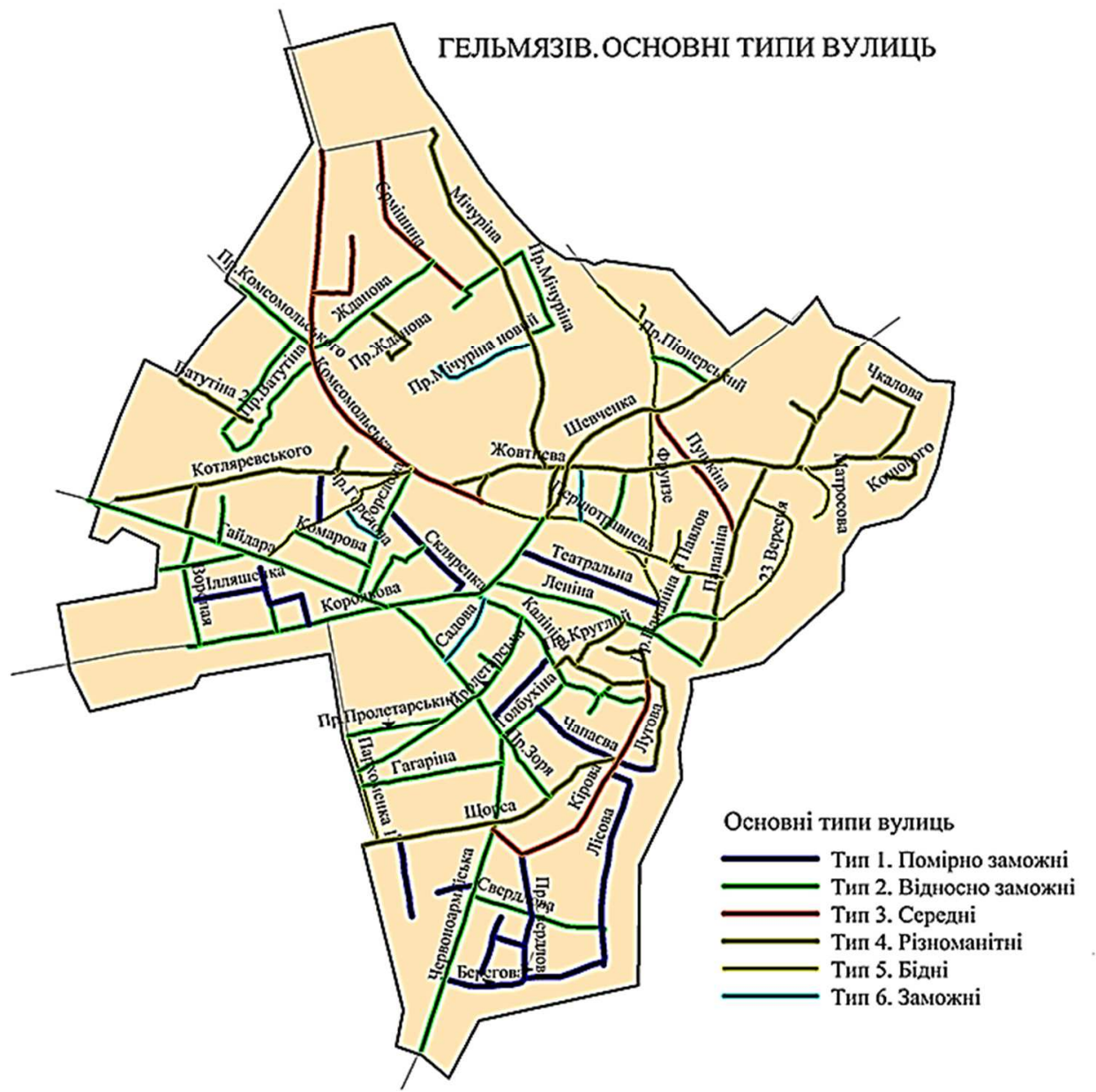

Рис. 2. Основні типи вулицьь

Було опитано 50 респондентів, серед яких осіб жіночої статі $64 \%$ та чоловічої $36 \%$; за віковим виділені такі групи респондентів: 15-20 років - 16\%; 21-35 років $34 \%$; 36-55 років - $26 \%$; старші за 50 років - $24 \%$. Серед них школярів було $6 \%$, студентів $-8 \%$, осіб, що не отримали освіти після закінчення школи, $-14 \%$, із середньою спеціальною освітою - 42 \%, 3 вищою - 30 \%. За місцем їхньої праці ми виділили такі категорії: обслуговуючі види праці (санітари, технічні працівники, продавці в магазинах, комірники та різноробочі) - 18 \%; «середньої ланки» види праці (оператор, кухар, ветеринарний лікар, газозварювальник, слюсар, будівельник) - 22 \% (основним критерієм у цьому випадку була середня спеціальна освіта); «керівники» - люди з вищою освітою (юрист, заступник директора, бухгалтер, учитель) - 14 \%. До категорії «пенсіонери/декрет» віднесено 20 \% респондентів; «школярів» - $6 \%$ та студентів - 4 \%; також безробітних виявлено - $16 \%$. За сімейним станом виявлено $42 \%$ одружених осіб; дали нечітку відповідь - $16 \%$; $14 \%$ - неодружених; тих, хто мають одного батька або одну матір зі всієї сім’ї - $12 \%$ та тих, хто мають лише дітей, $-6 \%$; одиноких людей, діти яких за кордоном, $-2 \%$. Розподіл за рівнем доходів, виявлений на основі суб'єктивних думок, такий: низькі доходи у $44 \%$ населення, середні - $40 \%$, утримались від відповіді $-14 \%$, мають іншу думку $-2 \%$, високі доходи - $0 \%$.

На питання щодо наявного місця проживання $68 \%$ вказали село, $10 \%$ - місто, 8 \% опитаних живуть у місті, а їхні сім’ї - в селі; $6 \%$ живуть у селі, а їхні сім’ї - в місті; $8 \%$ - не далі остаточної відповіді. 
ПРОБЛЕМИ МЕНЕДЖМЕНТУ ТА РОЗВИТКУ ПРОДУКТИВНИХ СИЛ РЕГІОНУ

На питання, чи задоволені жителі села місцем проживання, 68 \% відповіли, що їх все влаштовує, а $28 \%$ - не влаштовує. Більшість невдоволених висловили бажання жити в місті. Не дали відповідь $4 \%$.

На питання, що найбільше дошкуляє і заважає нормальному життю в цьому населеному пункті, 32 \% вибрали бідність (нездатність іiі подолати); $16 \%$ - роботу (або іiі відсутність); $16 \%$ - екологію; $10 \%$ - не вистачає чогось у житті; $8 \%$ - заважає оточення; $4 \%$ - мають іншу думку; $2 \%$ - сім'я; $2 \%$ - відсутність розваг; $4 \%$ - влаштовує все; $6 \%$ - утримались.

На питання, чи є мрія в людей переїхати і коли б вони хотіли це зробити, 44 \% відповіли, що ніколи; 32 \% - як тільки буде можливість; $10 \%$ - як виростуть діти; вказали власну думку - $6 \%$; не відповіли - $6 \%$; чекають, поки допрацюють до пенсії - $2 \%$.

На питання стосовно бажання респондентів змінити місце проживання та про можливі перешкоди цьому, 24 \% вказали, що не відчувають перспектив від можливого переїзду; 18 \% відповіли, що стримує страх за майбутнє; 18 \% відповіли, що не мають бажання змінювати місце проживання; $12 \%$ - не відповіли; інша причина - $6 \%$; відсутність коштів - $4 \%$; тримає сім'я - $2 \%$.

На питання, що тримає людей у рідному селі, 40 \% відповіли, що родинні зв'язки; $16 \%$ - могили батьків і рідних; $12 \%$ - усе влаштовує; $12 \%$ - «мені тут добре, я знайшов себе тут»; $10 \%$ - звичка; утримались - $8 \%$; нічого не тримає $-2 \%$.

На питання, чому люди живуть саме в селі, 32 \% відповіли, що отримали хорошу освіту і вдало застосували їі в селі; $12 \%$ - нікуди із села не їхали, не навчалися і їхній дім саме тут; $10 \%$ - рано одружилися, є діти, не до навчання; $14 \%$ - живуть на два поселення - поєднують село і місто; 8 \% - сімейні обставини (не дозволяє переїхати чоловік); $4 \%$ - бояться змін у житті; $4 \%$ - через любов до рідного села; $8 \%$ - такий вибір батьків; 8\% - не відповіли.

У питанні, чи доводилось людям бувати в іншому місті, 32 \% зазначили, що навчалися; $20 \%$ - жили у знайомих; $12 \%$ - були проїздом/на екскурсії; $8 \%$ - знаходились в лікарні або доглядали когось; $8 \%$ - виросли в місті; $6 \%$ - були на заробітках; подорожували $-2 \%$; інше $-8 \%$.

Стосовно того, як давно навчалися респонденти, з'ясовано, що $36 \%$ - при СРСР; $14 \%$ - навчаються нині, $14 \%$ - не навчалися взагалі; $12 \%$ - 5-10 років тому; $10 \%$ 10-20 років тому; $6 \%$ - 3-5 років тому; $8 \%$ - не відповіли.

Щодо уявлення сучасного міста в думках українського сільського населення, було виявлено такі тенденції: 58 \% - вважають, що в містах найкраща якість життя населення та найвищі заробітні плати; 24 \% - схиляються до думки, найкраще жити в сільській місцевості, бо міста непридатні для життя людини; $12 \%$ - не визначилися з відповіддю та $6 \%$ мають власну думку.

3 усіх опитаних $62 \%$ ніколи не були за кордоном; $16 \%$ - бували дуже рідко (1-2 рази в житті); $10 \%$ - відвідують періодично; $10 \%$ - бувають часто (більше 1-2 разів на рік); $2 \%$ - не відповіли.

Стосовно мети поїзди за кордон, 26 \% вказали - відпочинок; 22 \% - гості та друзі; $14 \%$ - робота і сфера інтересів; 38 \% - вибрали графу інше.

На питання, чи задоволене люди своєю заробітною платою, 14 \% вказали, що так, а 82 \% - що ні і 4 \% - було байдуже.

Серед потреб, задоволення яких вимагає найбільше зусиль для населення, 32 \% вибрали лікування, $26 \%$ - благоустрій присадибної ділянки; $22 \%$ - освіта/навчання дітей; $20 \%$ - одяг/взуття; $14 \%$ - харчування; $10 \%$ - опалення; $10 \%$ - домашнє господарство; $6 \%$ - задоволення вимагають всі потреби; $2 \%$ - відпочинок за кордоном; $2 \%$ - не мають ніяких проблем. 
Виявлено, що за станом матеріального забезпечення 46 \% респондентів значною мірою дошкуляють матеріальні складнощі; $46 \%$ - дошкуляють, але терпимо; 4 \% - утримались від відповіді; 2 \% - перебувають у нестерпному матеріальному становищі; 2 \% не мають $з$ цим проблем.

Серед причин, які є, на думку мешканців села, основною в усіх їхніх життєвих негараздах для 62 \% населення - це держава винна («якби політики менше крали, то населенню краще б жилось»); для $28 \%$ - «винні вони самі» («хто, як вони відповідальні за свій добробут»); для $8 \%$ - «винне саме суспільство»; $2 \%$ - мали свою відповідь.

$74 \%$ селян вважають, що вища освіта їм потрібна в житті, $20 \%$ - потрібна тільки за умови, якщо проживати в місті, бо в селі їі ніде застосувати; $4 \%$ - освіта не відіграє ніякої ролі в житті, заробляти вони вміють і так; 2 \% - утримались від відповіді.

За результатами соціального опитування можна зауважити, що диференціація умов життя на рівні домогосподарств у сільському населеному пункті утворюється завдяки уявленням місцевих мешканців про благополуччя і достаток та завдяки їхнім економічним ресурсам і можливостям вдосконалювати зовнішній вигляд житлових будівель i присадибних ділянок.

Дослідження сталого розвитку населеного пункту через показники умов життя, що включало диференціацію будинків за станом бідності / заможності та періодом економічного піднесення, а також опитування населення стосовно суб' єктивного сприйняття матеріального стану, дозволило виявити наступні потреби місцевих мешканців: потреба в лікування, благоустрою присадибної ділянки, освіті й навчанні дітей тощо. Ці потреби за результатами соціального опитування набрали найбільший відсоток. Саме благоустрій присадибної ділянки найбільше характеризує становище індивіда як заможного чи бідного в сільській місцевості.

Висновки і пропозиції. 1. Факторами, що впливають на сталий розвиток території локального рівня, можуть бути матеріальна спроможність чи неспроможність мешканців. У науковій літературі закордонних учених дослідження бідності спрямовані на визначення ролі індивіда в соціальному житті.

2. Дослідження особливостей сталого розвитку на локальному рівні через показники умов життя в сільському населеному пункті, що включало диференціацію будинків за станом привабливості та періодом економічного піднесення, а також опитування населення стосовно суб'єктивного сприйняття умов проживання, дозволило виявити, що на території одного населеного спостерігаються різні способи господарювання, відтворення життєдіяльності населенням тощо. Аналіз територіальної структури соціальної нерівності в населеному пункті дозволив виявити просторові особливості умов життєдіяльності населення. Виявлено, що зони бідності поширені в тій частині населеного пункту, яка історично сформована раніше.

3. Досліджено, що головною проблемою на шляху до сталого розвитку населеного пункту є бідність населення. Досягнення сталого розвитку регіону можливе при створенні організаційно-економічних механізмів стимулювання сталого розвитку регіо$\boldsymbol{\mu y}$, які можуть базуватись на інноваційних підходах промислової політики, зокрема на основі смартспеціалізації.

4. Регіональна інноваційна політика (смартспеціалізація регіону) може стати ключовим елементом для досягнення цілей сталого розвитку регіону, адже один 3 підходів до досягнення сталого розвитку базується на смартспеціалізації. Впровадження стратегій смартспеціалізації є одним ефективних методів для поліпшення гострих соціо-екологоекономічних регіональних проблем, адже реалізація стратегії смартспеціалізації вимагає визначення унікальних регіональних особливостей, що підвищують конкурентоспроможність регіону. 
ПРОБЛЕМИ МЕНЕДЖМЕНТУ ТА РОЗВИТКУ ПРОДУКТИВНИХ СИЛ РЕГІОНУ

5. Реалізація в державній політиці механізмів стимулювання сталого розвитку регіону в ключі смартспеціалізації може позитивно вплинути на вирівнювання умов життя населення за регіонами, що може підвищити якість життя населення. Вирівнювання умов життя населення та підвищення якості життя населення в регіоні за допомогою таких складних управлінських механізмів може стати драйвером позитивних трансформацій економіки як на регіональному, так і на локальному рівні.

\section{Список використаних джерел}

1. Алексеев А. И. Многоликая деревня (население и территория). Москва :Мысль, 1990. 266 с.

2. Бочаров Ю. П., Фильваров Г. И. Производство и пространственная организация городов. Москва :Стройиздат, 1987. $254 \mathrm{c.}$

3. Гукалова І. В. Якість життя населення України: суспільно-географічна концептуалізація : монографія. Київ : [б.в.], 2009. 347 с.

4. Демин Н. М. Управление развитием градостроительных систем. Киев: Будивэльнык, 1991. $184 \mathrm{c}$.

5. Іщук С. І., Гаєвська Н. С., Мельник І. Г. Бідність як соціально-економічна категорія й об’єкт дослідження суспільної географії. Економічна та соиіальна географія. 2011. Вип. 62. С. 56-64.

6. Картографическое исследование природопользования (теория и практика работ) / Руденко Л. Г. и др. Київ :Наукова думка, 1991. 212 с.

7. Малахов И. Н. Качество жизни: опыт экологического прочтения. Кривой Рог : ВЕЖА, 1999. $159 \mathrm{c}$.

8. Мисевич К. Н., Рященко С. В. Географическая среда и условия жизни населения Сибири. Новосибирск : Наука. Сибир. отд-ние, 1988. 120 с.

9. Покляцький С. А. Умови життя населення великих міст України: суспільно-географічне дослідження : [монографія] / відп. ред. І. В. Гукалової. Київ : Наукова думка, 2016. 185 с.

10. Социологическая энциклопедия / под общ. ред. А. Н. Данилова. Минск, 2003. 384 с.

11. Фащевский Н. И., Палий Т. М., Немченко М. П., Старостенко А. Г. Территориальная организация жизнедеятельности населения. Киев : Наук. думка, 1992. 136 с.

12. Bedrunka K. Concepts of the sustainable development of the region. Studies in Systems. Decision and Control. 2020. Vol. 198. Pp. 11-18.

13. Benjamin D., Hegetz O., Kimball M., Rees-Jones A. What Do You Think Would Make You Happier? What Do You Think You Would Choose? American Economic Review. 2012. Vol. 102. Pp. 2083-2110.

14. Di Tella R., Haisken-De New J., MacCulloch R. Happiness Adaptation to Income and to Status in an Individu $\neg$ al Panel. Journal of Economic Behavior and Organization. 2010. Vol. 76. Pp. 834-852.

15. Frey B., Stutzer A. What Can Economists Learn from Happiness Research? Journal of Economic Literature. 2002. Vol. 40. Pp. 402-435.

16. Galbraith John K. The Affluent Society (1958). Rev. ed. Boston: Houghton Mifflin, 1998. 336 p.

17. Graham C. Happiness Around the World: The Paradox of Happy Peasants and Unhappy Millionaires. Oxford University Press, 2012.

18. Kreslins K. Stefenberga D. Analysis of Kurzeme region development in the context of smart specialization strategy: Preliminary results. Engineering for Rural Development. 2016. January. Pp. 1224-1229.

\section{References}

1. Alekseev, A. I. (1990). Mnogolikaia derevnia (naselenie i territoriia) [Multifaceted village (population and territory)]. Mysl.

2. Bocharov, Yu. P., Filvarov, G. I. (1987). Proizvodstvo i prostranstvennaia organizatsiia gorodov [Production and spatial organization of cities]. Stroiizdat.

3. Gukalova, I. V. (2009). Yakist zhyttia naselennia Ukrainy: suspilno-heohrafichna kontseptualizatsiia [Quality of life of the population of Ukraine: socio-geographical conceptualization]. [w. p.].

4. Demin, N. M. (1991). Upravlenie razvitiem gradostroitelnyh system [Management of development of town-planning systems]. Budivelnyk. 
5. Ishchuk, S. I., Haievska, N. S., Melnyk, I. H. (2011). Bidnist yak sotsialno-ekonomichna katehoriia y obiekt doslidzhennia suspilnoi heohrafii [Poverty: socio-economic category and subject for human geography]. Ekonomichna ta sotsialna heohrafiia - Economic and social geography, 62, pp. 56-64.

6. Rudenko, L. G., Parxomenko, G. O., Molochko, A. M. (1991). Kartograficheskoe issledovanie prirodopol'zovanija (teorija i praktika rabot) [Cartographic study of nature management (theory and practice of works)]. Naukova dumka.

7. Malaxov, I. N. (1999). Kachestvo zhizni: opyt ekologicheskogo prochteniia [Quality of life: the experience of ecological reading]. VEZHA.

8. Misevich, K. N., Ryashhenko, S. V. (1988). Geograficheskaia sreda i usloviia zhizni naseleniia Sibiri [Geographical environment and living conditions of the population of Siberia]. Nauka. Sibir. otd-nie.

9. Pokliatskyi, S. A. (2016). Umovy zhyttia naselennia velykykh mist Ukrainy: suspilnoheohrafichne doslidzhennia [Living conditions of population in large cities of Ukraine: sociogeographical research]. Naukova dumka.

10. Danilov, A. N. (Ed.). (2003). Sotsiologicheskaia entsiklopediia [Sociological Encyclopedia]. Izdatelstvo "Belaruskaia Entsiklapediia".

11. Fashchevskyi, M. I., Palii, T. M., Nemchenko, M. P., Starostenko, A. G. (1992). Territorialnaia organizatsiia zhiznedeiatelnosti naseleniia [Territorial organization of life of the population]. Naukova dumka.

12. Bedrunka, K. (2020). Concepts of the sustainable development of the region. Studies in Systems, Decision and Control, 198, pp. 11-18.

13. Benjamin, D., Hegetz, O., Kimball, M., Rees-Jones, A. (2012). What Do You Think Would Make You Happier? What Do You Think You Would Choose? American Economic Review, 102, pp. 2083-2110.

14. Di Tella, R., Haisken-De New J., MacCulloch, R. (2010). Happiness Adaptation to Income and to Status in an Individual Panel. Journal of Economic Behavior and Organization, 76, pp. 834-852.

15. Frey, B., Stutzer, A. (2002). What Can Economists Learn from Happiness Research? Journal of Economic Literature, 40, pp. 402-435.

16. Galbraith John K. (1958). The Affluent Society. Houghton Mifflin.

17. Graham, C. (2012). Happiness Around the World: The Paradox of Happy Peasants and Unhappy Millionaires. Oxford University Press.

18. Kreslins, K. Stefenberga, D. (January, 2016). Analysis of Kurzeme region development in the context of smart specialization strategy: Preliminary results. Engineering for Rural Development (pp. 1224-1229).

\footnotetext{
Романченко Тетяна Тарасівна - аспірантка кафедри регіоналістики і туризму, ДВНЗ «Київський національний економічний університет імені Вадима Гетьмана» (просп. Перемоги, 54/1, м. Київ, 03057, Україна).

Романченко Татьяна Тарасовна - аспирантка кафедры регионалистики и туризма, ДВНЗ «Киевский национальный экономический университет имени Вадима Гетьмана» (пр. Победы, 54/1, г. Киев, 03057, Украина).

Romanchenko Tetiana - PhD student of the Department of Regional Studies and Tourism, Kyiv National Economic University named after Vadym Hetman (54/1 Peremohy Av., 03057 Kyiv, Ukraine).

E-mail: teromanchenko@gmail.com

ORCID: htpp://orcid.org./0000-0002-1663-1945
}

Романченко Т. Просторова трансформація економіки: локальний рівень (на прикладі с. Гельмязів Черкаської області). Проблеми $i$ перспективи економіки та управління. 2020. № 3(23). С. 73-82. 